\title{
Starostina O. V. Methodical support of teaching a foreign language in UK universities
}

The article deals with the peculiarities of the study and methodological support of teaching foreign languages at universities in the United Kingdom. It is noted that the methodological support for teaching foreign languages at UK universities and the possibility of using this experience in Ukraine have not been fully covered in the available scientific sources to date. In the meantime, there are many educational institutions in the UK that provide foreign language training. It is noted that in the system of teaching foreign students at UK universities, the leading role is given to the methodological provision and use of various learning tools, and the training environment offers a wide range of carefully selected learning resources that allow each student to work according to their own interests, desires and desires. It is established that the effective organization of a foreign language learning process at UK universities depends on both organizational and technical factors and a number of psychological and pedagogical conditions that need to be developed during the interaction of foreign language learning subjects. It is stated that the use of electronic language learning tools, which play the role of supporting the constructive efforts of the future specialist in acquiring knowledge and skills, is becoming more widespread. However, the success of the use of information and communication technologies for educational purposes is determined by the integration of traditional and innovative tools into the pedagogical system. It is stated that e-learning tools are able to more intensively achieve the goals of learning a foreign language as a professionally oriented discipline. It is concluded that the UK experience can be adopted when teaching foreign languages in Ukraine in order to approximate learning outcomes to the needs of students and employers within each professional area.

Key words: methodological support, foreign languages, United Kingdom, universities, educational process, information and communication technologies, professional orientation.

УДК [37.011.3-052:330]:378.4.046(043.5)

DOI https://doi.org/10.31392/NPU-nc.series5.2020.72-2.38

Стеблюк С. B.

\section{МЕТОДИЧНІ РЕКОМЕНДАЦІЇ ЩОДО ФОРМУВАННЯ ПРОФЕСІЙНОЇ КОМПЕТЕНТНОСТІ МАЙБУТНІХ ФАХІВЦІВ 3 ПІДПРИЄМНИЦТВА, ТОРГІВЛІ ТА БІРЖОВОї ДІЯЛЬНОСТІ}

Розглянуто методичні рекомендації до формування професійної компетентності майбутніх фахівців з підприємництва, торгівлі та біржової діяльності в системі ступеневої освіти. Визначено актуальність иієї проблеми та стан ї̈ розробки в наукових розвідках. 3'ясовано, щчо розроблено новий Стандарт вищої освіти, який формулює інтегральну, загальні, спеціальні компетентності, що потребує подальших досліджень за вищеназваною спеиіальністю. Окреслено зміст методичних рекомендацій, які були подані вченими у межах досліджуваної проблеми. Сформульовано мету й завдання статті. Метою є запропонувати викладачам методичні рекомендації щзодо формування професійної компетентності майбутніх фахівиів з підприємництва, торгівлі та біржової діяльності в системі ступеневої освіти; завданням стало визначення ключових рекомендаційних питань для удосконалення підготовки майбутніх фахівців з підприємництва. Запропоновано традииійні лекиійні заняття у модифікації автора, ї̈ структурних елементів, закиентовано увагу на авторській професійно-інтегративній технологї̈, щзо передбачала розробку інноваційних методів навчання. Визначено ї̈ переваги: можливість дослідити проблему иілісно у всіх ії виявах; зменшення диференціаціі у навчанні, посилення індивідуалізаиії; формування критичного та системного мислення, навичок прийняття рішень; урізноманітнення методів і прийомів навчання; створення психологічного комфорту. Запропоновано окремі інноваційні авторські методи навчання. Розкрито зміст деяких з них, наведено можливість їх застосування у проиесі викладання фахових дисциплін. Рекомендовано розробку силабусу як одного з видів навчально-методичного забезпечення. Закиентована увага на позааудиторній та науково-пошуковій діяльностях здобувачів освіти. Вказано на можливі шляхи удосконалення профорієнтаційної роботи, яка забезпечила б свідомий вибір абітурієнтами майбутньої професійної діяльності. Дослідження, проведене автором, довело ефективність конщепиії формування професійної компетентності майбутніх фахівиів з підприємництва, торгівлі та біржової діяльності.

Ключові слова: інновачійні методи навчання, концепція формування професійної компетентності майбутніх фахівців з підприємництва, торгівлі та біржової діяльності, методичні рекомендації, професійна компетентність, професійно-інтегративна технологія, силабус, освітній процес.

В Україні реформується професійна освіта, що зумовлено новим підходом до освітнього процесу - компетентнісним. Постановою Кабінету Міністрів від 29.04.2015 р. введено спеціальність 076 Підприємництво, торгівля та біржова діяльність галузі знань 07 Управління та адміністрування [3], що забезпечило широко профільну, інтегровану підготовку фахівців економічної сфери. Розроблено Стандарт вищої освіти, в якому подано перелік компетентностей - інтегральна, загальні, спеціальні. Це спонукало автора статті до проведення упродовж чотирьох років дослідження з проблеми формування професійної компетентності майбутніх фахівців з підприємництва, торгівлі та біржової діяльності в системі ступеневої освіти. Розглянуто теоретичні основи $з$ досліджуваного питання, практику підготовки майбутніх фахівців з підприємництва у Сполучених Штатах Америки, Канади та окремих країнах Європи; розроблено й апробовано концепцію 
формування професійної компетентності майбутніх фахівців з підприємництва, торгівлі та біржової діяльності. Результати наукового пошуку дали можливість запропонувати методичні рекомендації викладачам вищої освіти щодо підготовки майбутніх фахівців за цією спеціальністю.

Сьогодні має місце низка публікацій щодо формування професійної компетентності у майбутніх фахівців економічного профілю. Закцентовано увагу на дослідженнях: Н. Баловсяк (інформаційна компетентність економіста), С. Горобець (комп'ютерно орієнтовані технології навчання як засіб формування професійної компетентності студентів економічних спеціальностей), О. Грибанова (соціальна компетентність майбутніх економістів у процесі професійної підготовки в коледжі), Л. Дибкова (форми і методи індивідуального підходу у формуванні професійної компетентності майбутніх економістів), Є. Іванченко (формування професійної мобільності майбутніх економістів), Т. Наливайко (професійна компетентність майбутніх економістів засобами інноваційних технологій у процесі професійної підготовки), Н. Трішкіна (професійна компетентність фахівця торговельно-економічного профілю), Т. Фурман (професійна компетентність майбутніх фахівців економіки та підприємництва) та ін. Вченими закцентовано увагу на проблемах відповідно до мети дослідження та рекомендовано шляхи вдосконалення підготовки майбутніх фахівців економічної сфери. Відтак, Т. Фурман пропонує науково-педагогічному складу закладам вищої освіти упровадження у навчальний процес проблемних, пошукових, особистісно-орієнтованих, активних форм і методів навчання, які сприяють формуванню у студентів економічних спеціальностей мотивації саморозвитку та самовдосконалення, високого рівня активності щодо оволодіння професійними знаннями та уміннями; використання у навчальному процесі проблемних лекцій, лабораторних і практичних занять; психологічних тренінгів; дискусій і прес-конференцій; практикуму з розв’язування фахових задач різних рівнів складності, що включають вирішення психологічної проблеми [7, с. 14]. І. Власюк укладено методичні рекомендації до формування професійно-термінологічної компетентності студентів під час вивчення економічних дисциплін, де розкрито ефективність і результативність використання організаційно-педагогічних умов для розширення словника професійної термінології майбутніх економістів і розвитку вмінь використовувати фахові терміни в процесі вирішення професійних ситуацій [1, с. 184]. Для формулювання авторських методичних рекомендацій за основу взяті власний досвід професійної діяльності та наукові розвідки окремих учених $[2,4,5,6]$.

Мета дослідження - запропонувати викладачам методичні рекомендації щодо формування професійної компетентності майбутніх фахівців з підприємництва, торгівлі та біржової діяльності в системі ступеневої освіти. Завданням стало визначення ключових рекомендаційних питань 3 метою удосконалення підготовки майбутніх фахівців з підприємництва.

Методичні рекомендації щодо формування професійної компетентності у майбутніх фахівців 3 підприємництва, торгівлі та біржової діяльності подані за певними рівнями: на законодавчому (всеукраїнському); науково-методичному (закладам вищої освіти) та науково-педагогічним працівникам. У статті акцентуємо увагу на окремих із них.

Євроінтеграційні процеси, що відбуваються в освітньому просторі, вимагають модернізації методів, прийомів та форм навчання. Нами рекомендується удосконалення традиційних методів у структурі лекційно-практичних занять. Відтак, пропонувалися різні види лекцій (візуалізація, «удвох», дискусійна, бінарна та ін.). Найбільшій модифікації піддавалися тематичні лекції та іiі структурні елементи (вступна, викладення, висновки). До прикладу, з теми «Власність як економічна категорія» (дисципліна «Політекономія») студентам у вступній частині лекції визначено завдання провести гронування 3 питання «Економічні системи суспільства». Вони добирали ключові слова до попередньої теми, мотивували свій вибір. Викладачем доповнилося гронування низкою нових дефініцій, що дозволило мотивувати вивчення наступної теми та встановити зв'язок між економічними поняттями, явищами, що полегшило сприймання лекційного матеріалу, генерувало ідеї, сприяло розвитку критичного мислення та формувало економічну та підприємницьку складові професійної компетентності. 3-поміж інших варіантів для вступної частини лекції пропонувалися прийоми «покроковий успіх», «фолькльорна ув’язка». Приклад. Тема тематичної лекції довільна, етап заняття: вступна частина. Прийом «покроковий успіх». Лектор подає студентам текст для міркування про досягнення відомих економістів і пропонує доповнити його сучасними досягненнями у цій сфері (на основі Інтернет-джерел). Такий прийом забезпечив мотивацію до вивчення тем фахових дисциплін, прагнення до професійного розвитку, формував економічну та загальнокультурну складові професійної компетентності.

Прийом «фольклорна ув'язка» може застосовуватися на будь-якому лекційному занятті у вступній його частині. Студентам подається прислів'я економічної тематики (приказки) з окремих частин. Завдання: до початку прислів'я дібрати закінчення та пояснити їх зміст.

Спершу слід розсудити,

Торгівля кого виручить, та без боргів вставати

Чого нема - дорого,

Ліпше без вечері лягати,

Живи, не як хочеться,

Купець, що стрілець,

Хочеш гарно заробляти,

а як можеться.

а кого виучить.

чого багато - дешево.

а тоді купити.

треба добре працювати.

не доженеш. 
Такий прийом забезпечив частково-міждисциплінарну модель інтеграції, розвивав критичне мислення студентів.

Наступний етап лекції - викладення - включає факти, аналіз понять, характеристику різних підходів до економічних проблем, зв’язок з практичною діяльністю тощо. Це важлива їі частина, проте, як правило, вона носить пасивний характер для слухачів. Це спонукало нас до пошуків прийомів у викладанні, які мобілізували б їх до активного сприймання й аналізу інформації. Серед прийомів такі.

«Творче аудіювання». Викладач пропонував аудіотекст до одного 3 питань лекцій, студенти передавали ii зміст, записували незнайомий термін до цього пункту; викладач доповнював прослуханий текст і роз'яснював ключове слово. Спостереження за навчальною діяльністю показало, що запам'ятовування основних термінів таким прийомом є ефективним і пов'язує всі складові лекції. Трудність виникає в тому, що в сучасній професійній освіті недостатньо аудіотекстів економічного спрямування, тому вони записувалися автором, практичними працівниками. Вважаємо, що творче аудіювання забезпечить формування усіх складових професійної компетентності, комунікативно-діяльнісного їі компоненту, викличе інтерес до теми та дотичних до неї, мобілізує слухову активність студентів.

До заключної частини лекції пропонувалися прийоми «особистий розвиток», «незакінчена думка» тощо.

У процесі дослідження нами розроблено концепцію формування професійної компетентності майбутніх фахівців $з$ підприємництва, торгівлі та біржової діяльності, в основі якої авторська професійно-інтегративна технологія навчання, що може стати наскрізною на всіх освітніх ступенях. Це комплексна цілісна структура освітнього процесу на основі виявлення однотипних елементів у процесі засвоєння дисциплін за Освітньою програмою спеціальності, застосування інноваційних методів та прийомів навчання в аудиторній, позааудиторній та науково-дослідній роботі з метою формування складових професійної компетентності. Рекомендації до застосування авторської технології: з'ясування складових професійної компетентності; обрання ймовірних моделей інтеграції та побудова логічних схем до них; добірка методів і прийомів професійно-інтегративної технології навчання відповідно до теми та форми навчання (лекційна, практично-семінарська); залучення інноваційних комп'ютерних технологій навчання з метою забезпечення зворотнього зв'язку.

Очікувані результати застосування цієї технології передбачали готовність фахівця до підприємницької діяльності на основі сформованого комплексу складових професійної компетентності, що вкрай важливі в конкурентному економічному середовищі, здатності його до самоаналізу, навчанні упродовж життя із сформованими громадянськими, морально-етичними якостями. Перевагами визначено: можливість дослідити проблему цілісно, у всіх іï виявах; зменшення диференціації у навчанні, посилення індивідуалізації; формування критичного та системного мислення, навичок прийняття рішень; урізноманітнення методів і прийомів навчання; створення психологічного комфорту. Пропонуємо окремі інноваційні авторські методи навчання.

Метод ділової пропозиції. Застосовувався як різновид ділової гри на практичних заняттях, сприяв формуванню економічної, підприємницької компетентностей. Студентам, що об'єднані в групи, пропонувалося створити франчайзинг, продумати вид товару для франчайзі та умови його надання. Окрема група здобувачів освіти готувала проведення торгів з означеного товару. Вони пропонували для продажу не тільки власний товар, виготовлений із лози, вишивки тощо, але й назви марки фірми, рекламу, що є позитивним і попереджує економічний плагіат.

Метод «Під мікроскопом». Уводився на лекційному занятті у процесі проведення лекції «удвох», на семінарських чи практичних як доповнюючий елемент. Як правило, використовувався з метою залучення студентів до самостійної дослідницької роботи. Наприклад, до теми лекції «Етикет і культура ділових комунікацій» (дисципліна «Бізнес-комунікації. Бізнес-етика») заздалегідь пропонувалося завдання: оберіть одне iз торгівельних (біржових) підприємств області (міста, села), відоме Вам, що утримується на економічному ринку більше десяти років. В чому, на Вашу думку, його успіх і яка роль в розвитку регіону. Студенти висловлювали свої позиції щодо розвитку підприємництва, пропонували шляхи вирішення окремих питань, прогнозували розвиток бізнес-середовища регіону.

Метод «Професійний вузол». Використовувався як на лекційних, так і на практичних (семінарських) заняттях 3 метою встановлення причинно-наслідкових взаємозв'язків між бізнес-процесами. Алгоритм роботи: визначення теми, проблеми, яка підлягала аналізу; добірка основних понять теми, формулювання фактів, що є підтвердженням певних причин, понять; висновки та узагальнення.

До прикладу, з теми «Економічні потреби суспільства» розглядалась проблема закону зростання потреб. Студентами добиралися ключові поняття (потреба, структура потреб, виробництво, засоби праці, предмети праці, робоча сила та ін.) та сформулювалася проблема: зростання потреб і обмеженість виробничих ресурсів. 3'ясовано факти, що є підтвердженням причин: обмеженість виробничих ресурсів $\epsilon$ передумовою розвитку і формування ринку. Об'єктивною іiі основою стала дія закону рідкості, причиною існування якого є суперечності між безмежними потребами виробничих ресурсів. Як висновок, сутність будь-якого економічного закону показує причинно-наслідковий зв’язок певних економічних процесів. Завершилося вирішення цієї проблеми взаєморецензуванням та доповненням викладача. Апробація методу показала, що він є досить складним не тільки для студентів ОКР «молодший спеціаліст», а й ОС «бакалавр», «магістр».

Метод «Інтелект форум». Мав місце на практично-семінарських заняттях та забезпечив комплексносинтезовану модель інтеграції. сутність полягала в тому, що здобувачеві освіти запропоновано проблему 
дискусійного характеру для комплексного вирішення. Завдання виконувалося у малих групах, що мали можливість обмінюватися думками, доповнюючи позицію один одного. Орієнтовний зразок завдання. Поширеними на фінансовому ринку є фондові біржі, де відбувається торгівля акціями та цінними паперами. Цікавим є зарубіжний досвід, зокрема діяльності Чиказької товарної біржі. Завдання їі у наданні простору для ф'ючерної та опціонної торгівлі, зборі та систематизації інформації про ринок, підтримуванні клірингового механізму та контролю за виконанням правил торгівлі. Йде мова про ринок опціонів, ф'ючерних контрактів на сільськогосподарську продукцію, метали й кошти. Чи є ймовірність виникнення нестандартних ситуацій у проведенні біржових торгів, наведіть приклади.

Студентоорієнтоване середовище, як одна 3 педагогічних умов, вимагає нових підходів до створення навчально-методичного комплексу дисциплін. Вважаємо, що силабус є найбільш ефективним засобом зворотнього зв' язку. Він повинен містити чітку структуру, ключовими складовими якої є філософія дисципліни, iii зміст, сформовані компетентності, індивідуальна пошукова діяльність студента на основі сучасних наукових досліджень. Основними стейкголдерами повинні стати: викладачі, працедавці, студенти.

Однією з рекомендацій вважаємо створення сучасних засобів для підготовки майбутніх фахівців 3 підприємництва, серед яких комплекс електронних інформаційних програм навчального спрямування (подібного до навчання в загальноосвітніх навчальних закладах за програмою «Інтелект України»). Це сприятиме підвищенню якості освітнього процесу, забезпечить дистанційне навчання, посилить вимоги до компетентностей викладача та студента у застосуванні комп’ютерних технологій, інтеграції вітчизняної системи освіти в європейський освітній простір.

Результативність досліджуваної проблеми та авторської методики забезпечив взаємозв'язок складових освітнього процесу, в тому числі позааудиторної роботи, залучення студентів до розробок у стартапах, участь у грандових програмах. Цьому сприяла і продумана нестандартна система позааудиторної діяльності закладу, ефективна робота органу студентського самоврядування, міжнародна співпраця із закладами освіти, що сьогодні задекларовано майже усіма вишами, участь в різних програмах, обмінах студентами тощо. На основі методу сінемалогії ознайомлено студентів із кращими підприємцями країни, практикою ведення підприємництва за кордоном, світовим визнанням окремих бізнес-проектів і їх авторами.

Безперечно, результативність формування професійної компетентності майбутніх фахівців 3 підприємництва, торгівлі та біржової діяльності забезпечить науково-пошукова діяльність, що вимагає вдосконалення тематики курсових, дипломних (магістерських) робіт, участь у конференціях різних видів. Проведення спільних наукових досліджень із студентами сприятиме з'ясуванню проблем в галузі підприємництва, торгівлі та біржової діяльності, бачення їх вирішення; розвиватиме загальнокультурну складову професійної компетентності.

Рекомендуємо закцентувати увагу на формуванні у здобувачів освіти морально-етичних цінностей, так як підприємець діє в конкурентних умовах і такі чесноти як відповідальність, чесність, дисциплінованість, толерантність, відвага мають бути першочерговими. Просвітницька діяльність пріоритетів демократичного суспільства, цінностей людини повинна набирати комплексного характеру й нового змісту.

Сучасність вимагає оновлення профорієнтаційної роботи з метою формування мотивації до здобуття освіти із залученням усіх соціальних груп, випускників різних освітніх ступенів, батьків. Споживацьке відношення в окремих випадках до майбутньої професії (за принципом: це вигідно) повинно бути замінене ідеєю «сродної праці». Розробка комплексної профорієнтаційної роботи на електронних носіях, спеціальної літератури про потреби вітчизняного ринку має стати наступним важливим пріоритетом розвитку закладу вищої освіти. Як один із шляхів реалізації цього завдання вбачаємо у проведенні спільних заходів вишів та закладів середньої освіти, серед яких «Кращий бізнес-проект», «Моя бізнес-справа», що проводилися автором дослідження і показали свою ефективність; залучення роботодавців до цього процесу, спілкування із здобувачем в соціальній мережі щодо пріоритетів та труднощів у майбутній професійній діяльності 3 підприємництва, торгівлі та біржової діяльності. Нерозуміння абітурієнтами та батьками окремих труднощів фаху, його специфіки призводить до психологічного дискомфорту, розчарування, що, як правило, завершується відрахуванням із числа студентів. Тому профорієнтаційна робота повинна грунтуватися не тільки на залученні до навчання у певному виші, а на реальних даних особливостей майбутньої діяльності. Окрім цього, закладам вищої освіти вкрай важливо розробити програми перекваліфікації безробітних, залучення їх до створення спільних бізнес-проектів.

Висновки. Таким чином, нами запропоновано методичні рекомендації до формування професійної компетентності майбутніх фахівців з підприємництва, торгівлі та біржової діяльності в системі ступеневої освіти. Вони сформульовані на основі наукового пошуку щодо авторської концепції підготовки здобувачів освіти цього профілю. Запропоновано традиційні лекційні заняття у модифікації автора, її структурних елементів. Особлива увага закцентована на професійно-інтегративній технології, що передбачала інноваційні методи навчання, які довели результативність ії застосування. Для створення студентоорієнтованого середовища рекомендовано силабус як одного з видів навчально-методичного забезпечення.

Перспектива подальшого дослідження вбачається у розробці методичних рекомендацій інтегрованого спецкурсу «Підприємництво, торгівля та біржова діяльність». 


\section{Використана література:}

1. Власюк I. В. Формування професійно-термінологічної компетентності майбутніх бакалаврів економіки в процесі вивчення фахових дисциплін : дис. ... канд. пед. наук : 13.00.04 / Вінницький державний педагогічний університет імені Михайла Коцюбинського. Вінниця, 2015. 264 с.

2. Охріменко I. В. Кадрове забезпечення вітчизняного біржового ринку. Інтернаука. Сер.: Економічні науки. Фінансовокредитна і грошова політика: міжнар. наук. журн. 2017. № 1 (1). С. $27-36$.

3. Про затвердження переліку галузей знань і спеціальностей, за якими здійснюється підготовка здобувачів вищої освіти: Постанова Кабінету Міністрів України від 29 квітня 2015 р. № 266. URL: https://zakon.rada.gov.ua/laws/ show/266-2015- \%D0 \%BF (дата звернення: 05.01.2020).

4. Романовський О. О. Теорія і практика підприємницької освіти в розвинутих зарубіжних країнах : автореф. дис. ... д-ра пед. наук : 13.00.01 / Національний педагогічний університет імені М. П. Драгоманова. Київ, 2003. 39 с.

5. Романовський О. О. Академічне підприємництво як чинник інноваційного розвитку сфери вищої освіти і науки України. Вісник Київського національного університету технологій та дизайну. Сер.: Економічні науки. 2015. № 4. С. $37-51$.

6. Трішкіна Н. Сучасні підходи до формування професійних компетенцій фахівців торговельно-економічного профілю. Вісник Дніпропетровського університету імені Альфреда Нобеля. Сер.: Педагогіка і психологія. Педагогічні науки. 2015. № 1 (9). С. 193-197.

7. Фурман Т. Ю. Формування професійної компетентності у майбутніх фахівців економіки та підприємництва в процесі вивчення економічних дисциплін : автореф. дис. ... канд. пед. наук : 13.00.04 / Нац. авіац. ун-т. Київ, 2012. 21 с.

\section{References:}

1. Vlasiyk I. V. Formuvannya profesijno-terminologichnoyi kompetentnosti majbutnix bakalavriv ekonomiky v procesi vyvchennya faxovyx dyscyplin: [Formation of professional and terminological competence of bachelor of economics in the study of professional disciplines]: dys. ... kand. ped. nauk: 13.00.04 / Vinnyczkyj derzhavnyj pedagogichnyj universytet imeni Myxajla Kocyubynskogo. Vinnycya, 2015. 264 s. [in Ukrainian]

2. Okhrimenko I. V. Kadrove zabezpechennya vitchyznyanogo birzhovogo rynku [Staffing of domestic exchange market]. Internauka. Cer.: Ekonomichni nauky. Finansovo-kredytna i groshova polityka: mizhnar. nauk. zhurn. 2017. 1 (1). S. 27-36 [in Ukrainian]

3. Pro zatverdzhennya pereliku galuzej znan i specialnostej, za yakymy zdijsnyuyetsya pidgotovka zdobuvachiv vyshhoyi osvity [On approval of the list of branches of knowledge and specialties by which higher education applicants are trained]. Postanova Kabinetu Ministriv Ukrayiny vid 29 kvitnya 2015 r. URL: https://zakon.rada.gov.ua/laws/show/266-2015- \%D0 \%BF (data zvernennya: 05.01.2020).

4. Romanovskii O. O. Teoriya i praktyka pidpryyemnyczkoyi osvity v rozvynutyx zarubizhnyx krayinax [Entrepreneurship education theory and practice in the developed foreign countries]: avtoref. dys. ... d-ra ped. nauk: 13.00.01 / Nacionalnyj pedagogichnyj universytet imeni M. P. Dragomanova. Kyiv, 2003. 39 s. [in Ukrainian]

5. Romanovskii O. O. Akademichne pidpryyemnycztvo yak chynnyk innovacijnogo rozvytku sfery vyshhoyi osvity i nauky Ukrayiny [Academic entrepreneurship as a factor of innovative development of the sphere of higher education and science of Ukraine] Visnyk KNUTD. Ser.: Ekonomichni nauky. 2015. № 4. S. 37-51 [in Ukrainian].

6. Trishkina N. I. Suchasni pidxody do formuvannya profesijnyx kompetencij faxivciv torgovelno-ekonomichnogo profilyu [New approaches to the formation of experts with professional competence in trade and economic profile] Visnyk Dnipropetrovskogo universytetu imeni Alfreda Nobelya. Seriya «Pedagogika i psyxologiya». Pedagogichni nauky, 2015. 1 (9). P. 193-197 [in Ukrainian].

7. Furman T. Y. Formuvannya profesijnoyi kompetentnosti u majbutnix faxivciv ekonomiky ta pidpryyemnycztva v procesi vyvchennya ekonomichnyx dyscyplin [Formation of professional competence of future specialists of economics and enterprise in the process of learning of economic disciplines] avtoref. dys. ... kand. ped. nauk: 13.00.04 / Nacz. aviacz. un-t. Kyiv, 2012. $21 \mathrm{~s}$. [in Ukrainian].

\section{Stebljuk S. V. Methodical recommendations on the formation of professional competence in future specialists of entrepreneurship, trade and exchange activities}

The article describes methodical recommendations to formation of professional competence in future specialists of entrepreneurship, trade and exchange activities in the system of multy-degree education. The relevance of the problem and the status of its development in scientific research is shown. It was also found out that a new Standard of higher education (which formulates an integral, general, special expertise) requires further studies on the courses. The content of the guidelines, which were presented by scientists in the framework of the research problem is revealed. Goal and tasks of the article are formulated. The goal is to offer teachers the methodical recommendations on the formation of professional competence in future specialists of entrepreneurship, trade and exchange activities in the system of multy-degree education; goal was also to identify key issues recommendations which aim to improve training of future specialists of entrepreneurship. Traditional lectures in the author's modification are offered, emphasis is put on their structural elements, special attention is paid to the author's vocational-integrating technology, which includes development of innovative teaching methods. The benefits are found out: the opportunity to explore the issue holistically in all its manifestations; the decrease of differentiation in teaching, increase of individualization; formation of critical and system thinking, decision-making skills; a variety of methods and techniques of training; creation of psychological comfort. Innovative original teaching methods are offered. The contents of some of them are revealed, given the possibility of their usage in the teaching of professional disciplines. The development of the syllabus as one of the types of training and methodological support is recommended. Also attention is focused on extracurricular and scientific research of students. Possible ways to improve career guidance that would ensure a conscious choice of a job by prospective students are listed. Research conducted by the author demonstrated the effectiveness of the concept of formation of professional competence in future specialists of entrepreneurship, trade and exchange activities.

Key words: innovative teaching methods, professional competence, the concept of formation of professional competence in future specialists of entrepreneurship, trade and exchange activities; methodical recommendations, vocational and integrative technology, syllabus, educational process. 